\title{
Obtaining the Minimum Lethal Dose against Fasciola hepatica in Vitro Using Plant Extract Hexanes with Fasciolicide Activity and Toxicity Evaluation on CD1 Male Mice
}

\author{
Stephanie Ibarra-Moreno ${ }^{1,2 *}$, Froylan Ibarra-Velarde ${ }^{1}$, Jose Guillermo Avila-Acevedo ${ }^{2}$ \\ ${ }^{1}$ Depto de Parasitología, Facultad de Medicina Veterinaria, Y Zootecnia, UNAM, Ciudad Universitaria, México D.F., México; ${ }^{2}$ Lab. \\ de Fitoquímica, UBIPRO, Facultad de Estudios Superiores Iztacala, UNAM, Avenida de los Barrios S/N Tlalnepantla de Baz, Edo. \\ de México. \\ Email: *stephibamor@hotmail.com
}

Received January $11^{\text {th }}, 2012$; revised February $19^{\text {th }}$, 2012; accepted March $16^{\text {th }}, 2012$

\begin{abstract}
Fascioliasis is a parasitic disease of worldwide distribution affecting mainly cattle and sheep. Its importance lies in the economic losses it produces in the livestock industry. Its control is carried out by using a chemical fasciolicide showing resistance problems and environmental contamination. Looking for an alternative control for this disease the present study was aimed at determining the hexane anti-Fasciola hepatica in the in vitro effect of some plant extracts and the minimum lethal dose of the mentioned extracts. All selected plants were tested in vitro at concentrations of 500, 250, 125 and $50 \mathrm{mg} / \mathrm{L}$ ): Achilleamillefolium (plumajillo), Artemisiaabsinthium (wormwood), Artemisia mexicana (estafiate), Castelatortuousa (chaparroamargo), Chenopodiumgraveolens (epazote de zorrillo), Gymnospermaglutinosum (popote) Justicia spicigera (muicle), Limpia critridora (cedron), Lippiagraveolens (oregano), Menthapiperita (Mint), Populus alba (alamo) and Thymusvulgaris (thyme). Subsequently proceeded to perform a toxicity study with these fractions in CD1 male mice 10 - 13 weeks of age, forming groups of 3 - 5 animals they were administered a single oral dose being $(5 \mathrm{mg} / \mathrm{kg}, 50 \mathrm{mg} / \mathrm{kg}, 500 \mathrm{mg} / \mathrm{kg}, 2500 \mathrm{mg} / \mathrm{kg}$ and $5000 \mathrm{mg} / \mathrm{kg}$ ) and were kept under observation 20 days, later were sacrificed and a kidney and liver histology was performed, finding the safety of the extracts. To perform the toxicity study with these fractions, groups of five CD1 male-mice were formed, they were treated with oral doses of 5, 50, 500, 2500 and $5000 \mathrm{mg} / \mathrm{kg}$, administered with a cannule. All mice were kept under observation for 20 days. Finally they were sacrificed to perform histology of the kidney and liver in search of possible side effects. Results show that none of the extracts exhibited that fasciolocide activity for mice CD1 even at the highest dose thereforefinding the safety of the extracts.
\end{abstract}

Keywords: Fasciola hepatica; Plant Extracts; In Vitro; Minimum Lethal Dose; Toxicity

\section{Introduction}

Fasciolosis is a parasitic disease of worldwide distribution [1]. It is due to the action of the liver fluke Fasciola hepatica, which affects primarily cattle and sheep and other animal species including humans [2]. Its importance lies in the resulting economic losses it produces in the livestock industry, which can be reduced through chemical treatment of livestock [3,4].

Over the years the private industry has tried to improve diagnostic methods and promote the production of more effective drugs with the purpose of obtaining a comprehensive control of this trematodosis [5,6]. How-

${ }^{*}$ Corresponding author. ever, since the parasites eventually develop resistance to these drugs, alternative methods such as the study of active substances of several plants with anthelmintic properties were considered essential to study [7].

Mexico is the fourth place worldwide in floristic diversity with more than 25,000 recorded species, of the 250,000 that exist in the world and there are estimated to be 30,000 more within the national-territory; the country's forest area comprises $73.3 \%$ of its territory. Moreover, there are over 6000 species of medicinal plants reported so far $[8,9]$.

Based on ethnobotanical studies we have found different plants used in Mexican traditional medicine against dysentery, vomiting, vermifuge, nausea, poor absorption, 
diarrhea, indigestion, etc. [10,11]. From these plants we have processed hexane extracts which were previously tested an in vitro model against immature stages of Fasciola hepatica, yielding an efficiency of between $80 \%$ $100 \%$ in the first 3 days at a concentration of $500 \mathrm{mg} / \mathrm{Lt}$ [12]. The following plants were selected for screening:
Achilleamillefolium (plumajillo)
Artemisia absinthium (wormwood)
Artemisia mexicana (estafiate)
Castela tortuosa (chaparro amargo)
Chenopodiumgraveolens (epazote de zorrillo)
Gymnospermaglutinosum (popote)
Justicia spicigera (muicle)
Limpia critridora (cedron)
Lippiagraveolens (oregano)
Menthapiperita (mint)
Populus alba (alamo)
Thymusvulgaris (thyme)

\section{Materials and Methods}

\subsection{Preparation of Plant Extracts}

The plant parts (leaves, flowers and stems) were extracted with a hexane solvent using a rota-evaporator. Then 3 distillations were performed every 3 - 4 days depending on the plant. The extracts were concentrated in different vials for later evaluation.

\subsection{In Vitro Fasciolicide Evaluation of the Minimum Lethal Dose with Hexane Extracts}

These evaluations were conducted in the Experimental
Chemotherapy Laboratory, Department of Parasitology, College of Veterinary Medicine of the National Autonomous University of Mexico (Figure 1).

\subsection{Preparation of Plant Extracts for Evaluation}

$5 \mathrm{mg}$ of extract were placed in vials of $30 \mathrm{ml}$. Then the corresponding dilutions were prepared so as to obtain the concentrations required for the anti-Fasciola hepatica biological evaluation, these being ( $500 \mathrm{mg} / \mathrm{L}, 250 \mathrm{mg} / \mathrm{L}$, $125 \mathrm{mg} / \mathrm{L}$ and $50 \mathrm{mg} / \mathrm{L}$ ).

\subsection{Operation of the Test for Screening}

Culture dishes of 24 Nunc brand wells were used. For each well $1.6 \mathrm{ml}$ of complete medium there was deposited $0.2 \mathrm{ml}$ of a solubilized extract and $0.2 \mathrm{ml}$ containing 10 newly excysted flukes per well. Each trial remained in incubation for 4 days at $37^{\circ} \mathrm{C}$ under an atmosphere of $5 \%$ $\mathrm{CO}_{2}$.

\subsection{Interpretation of the Test}

The flukes were examined carefully on days 1.2 and 3 using an inverted microscope at $40 \times$. The activity of the extracts was assessed by a comparison of the surviving treated flukes with the untreated control flukes. All procedures were performed under sterile conditions using a laminar flow cabinet, as previously described by Rivera [13].

\% Efficacy was assessed using the following formula [14]:

No. of flukes in the control group - No. of flukes in the treated group $\times 100$

No. of the flukes in the control group

\subsection{Evaluation of Acute Toxicity in Mice CD1}

CD1 male mice were formed in groups of 5 animals each. They were treated with different oral doses of the extracts previously selected. We use CD1 mice because they are strong, economical, easily produced and used in biological assays or in preliminary studies where the specific genotype is not important.

Extracts were prepared as a suspension/solution at concentrations of $500 \mathrm{mg} / \mathrm{L}, 250 \mathrm{mg} / \mathrm{L}, 125 \mathrm{mg} / \mathrm{L}$ and 50 $\mathrm{mg} / \mathrm{L}, 2$ - $5 \mu \mathrm{l}$ absolute alcohol was used to dissolve the extract plus 995 - $998 \mu$ l of methyl cellulose as a vehicle. The suspension was administered with a cannule and the mice were under observation for 20 days (appetite, hair, motor activity, mucous etc.). The untreated control group $(n=6)$ dosed only with absolute alcohol + methyl cellulose was also observed in the same manner. Finally mice were sacrificed to carry out the histopathology of the

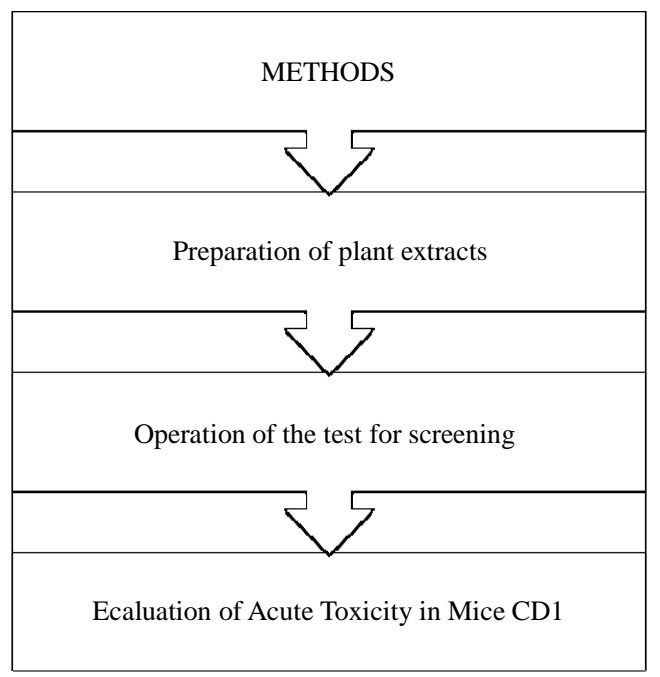

Figure 1. Methodology. 
liver and kidney searching for possible toxic side effects.

\section{Results and Discussion}

Table 1 shows the in vitro fascioliscide activity of the hexanes plant extractshere is the scientific name, common name, number of flukes used, concentration used, and effectiveness for three days.

It is important to note only the hexane fraction was used in these trials because this fraction was shown to have the most effective in previous trials [15] and we can therefore assume that it is a metabolite or an active principle that is common in these plants that produce this fasciolicide effect. It was found, as shown in (Table 2) the minimum lethal dose of hexane extracts with fasciolicide activity in percent. Finally it is shown in (Table 2) the toxicity of hexane extracts in CD1 male mice for 20 days. In all in vitro tests were no controls with the same amount of solvent to solubilize the extracts and always remained alive for up to 7 days and in the same way the control miceremained healthy with methyl celluloseas a vehicle utilized.

Plants are a resource for obtaining new drugs and treatments for existing parasitic diseases in our country. $[9,14,15]$ Ethnobotanical studies are very useful to locate

Table 1. In vitro fasciolicide activity of the hexanes plant extracts.

\begin{tabular}{|c|c|c|c|c|c|c|}
\hline Plant & Total flukes & Concen-tration & 1 Day efficacy & 2 Day efficacy & 3 Day efficacy & Part of the plant used \\
\hline $\begin{array}{l}\text { Achilleamillefolium } \\
\text { (Plumajillo) }\end{array}$ & $\begin{array}{l}70 \\
70 \\
70 \\
40\end{array}$ & $\begin{array}{c}500 \mathrm{mg} / \mathrm{L} \\
250 \mathrm{mg} / \mathrm{L} \\
125 \mathrm{mg} / \mathrm{L} \\
50 \mathrm{mg} / \mathrm{L}\end{array}$ & $\begin{array}{c}100 \% \\
100 \% \\
100 \% \\
0 \%\end{array}$ & $\begin{array}{c}100 \% \\
100 \% \\
100 \% \\
0 \%\end{array}$ & $\begin{array}{c}100 \% \\
100 \% \\
100 \% \\
10 \%\end{array}$ & Leaf, flower stem \\
\hline $\begin{array}{l}\text { Artemisia absinthium } \\
\text { (wormwood) }\end{array}$ & $\begin{array}{l}70 \\
70 \\
40\end{array}$ & $\begin{array}{l}500 \mathrm{mg} / \mathrm{L} \\
250 \mathrm{mg} / \mathrm{L} \\
125 \mathrm{mg} / \mathrm{L}\end{array}$ & $\begin{array}{c}98 \% \\
70 \% \\
0 \%\end{array}$ & $\begin{array}{c}100 \% \\
100 \% \\
0 \%\end{array}$ & $\begin{array}{c}100 \% \\
100 \% \\
10 \%\end{array}$ & Leaf and stem \\
\hline $\begin{array}{l}\text { Artemisia mexicana } \\
\text { (estafiate) }\end{array}$ & $\begin{array}{l}70 \\
70 \\
70 \\
40\end{array}$ & $\begin{array}{c}500 \mathrm{mg} / \mathrm{L} \\
250 \mathrm{mg} / \mathrm{L} \\
125 \mathrm{mg} / \mathrm{L} \\
50 \mathrm{mg} / \mathrm{L}\end{array}$ & $\begin{array}{c}94 \% \\
80 \% \\
60 \% \\
0 \%\end{array}$ & $\begin{array}{c}100 \% \\
100 \% \\
100 \% \\
0 \%\end{array}$ & $\begin{array}{c}100 \% \\
100 \% \\
100 \% \\
0 \%\end{array}$ & Leaf and stem \\
\hline $\begin{array}{l}\text { Castelatortuosa } \\
\text { (chaparroamargo) }\end{array}$ & $\begin{array}{l}70 \\
60 \\
40 \\
40\end{array}$ & $\begin{array}{c}500 \mathrm{mg} / \mathrm{L} \\
250 \mathrm{mg} / \mathrm{L} \\
125 \mathrm{mg} / \mathrm{L} \\
50 \mathrm{mg} / \mathrm{L}\end{array}$ & $\begin{array}{c}100 \% \\
100 \% \\
80 \% \\
0 \%\end{array}$ & $\begin{array}{c}100 \% \\
100 \% \\
100 \% \\
0 \%\end{array}$ & $\begin{array}{c}100 \% \\
100 \% \\
100 \% \\
0 \%\end{array}$ & Leaf and stem \\
\hline $\begin{array}{l}\text { Chenopodiumgraveolens } \\
\text { (epazote de zorrillo) }\end{array}$ & $\begin{array}{l}60 \\
40 \\
20\end{array}$ & $\begin{array}{l}500 \mathrm{mg} / \mathrm{L} \\
250 \mathrm{mg} / \mathrm{L} \\
125 \mathrm{mg} / \mathrm{L}\end{array}$ & $\begin{array}{c}98 \% \\
0 \% \\
0 \%\end{array}$ & $\begin{array}{c}100 \% \\
0 \% \\
0 \%\end{array}$ & $\begin{array}{c}100 \% \\
10 \% \\
0 \%\end{array}$ & Leaf, flower and stem \\
\hline $\begin{array}{c}\text { Gymnospermaglutinosum } \\
\text { (Popote) }\end{array}$ & $\begin{array}{l}60 \\
40 \\
20\end{array}$ & $\begin{array}{l}500 \mathrm{mg} / \mathrm{L} \\
250 \mathrm{mg} / \mathrm{L} \\
125 \mathrm{mg} / \mathrm{L}\end{array}$ & $\begin{array}{c}60 \% \\
0 \% \\
0 \%\end{array}$ & $\begin{array}{c}100 \% \\
10 \% \\
0 \%\end{array}$ & $\begin{array}{c}100 \% \\
20 \% \\
0 \%\end{array}$ & Leaf and stem \\
\hline $\begin{array}{l}\text { Justicia spicigera } \\
\text { (Muicle) }\end{array}$ & $\begin{array}{l}60 \\
70 \\
40\end{array}$ & $\begin{array}{l}500 \mathrm{mg} / \mathrm{L} \\
250 \mathrm{mg} / \mathrm{L} \\
125 \mathrm{mg} / \mathrm{L}\end{array}$ & $\begin{array}{c}100 \% \\
80 \% \\
0 \%\end{array}$ & $\begin{array}{c}100 \% \\
100 \% \\
0 \%\end{array}$ & $\begin{array}{c}100 \% \\
100 \% \\
0 \%\end{array}$ & Leaf and stem \\
\hline $\begin{array}{l}\text { Limpiacritridora } \\
\text { (Cedrón) }\end{array}$ & $\begin{array}{l}60 \\
60\end{array}$ & $\begin{array}{l}500 \mathrm{mg} / \mathrm{L} \\
250 \mathrm{mg} / \mathrm{L}\end{array}$ & $\begin{array}{c}70 \% \\
0 \%\end{array}$ & $\begin{array}{c}80 \% \\
0 \%\end{array}$ & $\begin{array}{c}88 \% \\
0 \%\end{array}$ & Leaf and stem \\
\hline $\begin{array}{l}\text { Lippiagraveolens } \\
\text { (orégano) }\end{array}$ & $\begin{array}{l}60 \\
70 \\
40\end{array}$ & $\begin{array}{l}500 \mathrm{mg} / \mathrm{L} \\
250 \mathrm{mg} / \mathrm{L} \\
125 \mathrm{mg} / \mathrm{L}\end{array}$ & $\begin{array}{c}100 \% \\
80 \% \\
0 \%\end{array}$ & $\begin{array}{c}100 \% \\
90 \% \\
10 \%\end{array}$ & $\begin{array}{c}100 \% \\
100 \% \\
10 \%\end{array}$ & Leaf and stem \\
\hline Mentha piperita (Mint) & $\begin{array}{l}70 \\
70 \\
70 \\
40\end{array}$ & $\begin{array}{c}500 \mathrm{mg} / \mathrm{L} \\
250 \mathrm{mg} / \mathrm{L} \\
125 \mathrm{mg} / \mathrm{L} \\
50 \mathrm{mg} / \mathrm{L}\end{array}$ & $\begin{array}{c}100 \% \\
80 \% \\
60 \% \\
0 \%\end{array}$ & $\begin{array}{c}100 \% \\
100 \% \\
100 \% \\
0 \%\end{array}$ & $\begin{array}{c}100 \% \\
100 \% \\
100 \% \\
0 \%\end{array}$ & Leaf and stem \\
\hline Populus alba (Álamo) & $\begin{array}{l}60 \\
40 \\
20\end{array}$ & $\begin{array}{l}500 \mathrm{mg} / \mathrm{L} \\
250 \mathrm{mg} / \mathrm{L} \\
125 \mathrm{mg} / \mathrm{L}\end{array}$ & $\begin{array}{c}100 \% \\
0 \% \\
0 \%\end{array}$ & $\begin{array}{c}100 \% \\
20 \% \\
0 \%\end{array}$ & $\begin{array}{c}100 \% \\
20 \% \\
0 \%\end{array}$ & Leaf and stem \\
\hline Thymus vulgaris (thyme) & $\begin{array}{l}70 \\
60 \\
20\end{array}$ & $\begin{array}{l}500 \mathrm{mg} / \mathrm{L} \\
250 \mathrm{mg} / \mathrm{L} \\
125 \mathrm{mg} / \mathrm{L}\end{array}$ & $\begin{array}{c}71 \% \\
0 \% \\
0 \%\end{array}$ & $\begin{array}{c}88 \% \\
0 \% \\
0 \%\end{array}$ & $\begin{array}{c}99 \% \\
0 \% \\
0 \%\end{array}$ & Leaf, flower and stem \\
\hline
\end{tabular}


Table 2. Minimum lethal dose of hexane extracts with fasciolocide activity (in vitro model).

\begin{tabular}{cc}
\hline Extract hexanic & $\begin{array}{c}\text { Minimum lethal dose } \\
\text { in vitro (\%) }\end{array}$ \\
\hline Achilleamillefolium (plumajillo) & $125 \mathrm{mg} / \mathrm{L}$ \\
Artemisia mexicana (estafiate) & $125 \mathrm{mg} / \mathrm{L}$ \\
Castela tortuosa (chaparro amargo) & $125 \mathrm{mg} / \mathrm{L}$ \\
Menthapiperita (mentha) & $125 \mathrm{mg} / \mathrm{L}$ \\
Justicia spicigera (muicle) & $250 \mathrm{mg} / \mathrm{L}$ \\
Lippiagraveolens (oregano) & $250 \mathrm{mg} / \mathrm{L}$ \\
Artemisia absinthium (Ajenjo) & $500 \mathrm{mg} / \mathrm{L}$ \\
Chenopodiumgraveolens (epazote de zorrillo) & $500 \mathrm{mg} / \mathrm{L}$ \\
Gymnospermaglutinosum (Popote) & $500 \mathrm{mg} / \mathrm{L}$ \\
Limpiacritridora (Cedron) & $500 \mathrm{mg} / \mathrm{L}$ \\
Populus alba (alamo) & $500 \mathrm{mg} / \mathrm{L}$ \\
& $500 \mathrm{mg} / \mathrm{L}$ \\
\hline
\end{tabular}

plants as possible prospects for the use of new antiparasitic drugs [10,14,16]. Various plants had previously been studied, obtained and processed to find several hexane extracts with fasciolicide activity in the in vitro model [15].

Thus in the present study we worked with these same extracts at different concentrations to find the minimum lethal dose in vitro since it was found that not all the hexane extracts had the same fasciolicide activity [15].

The results obtained showed that Achilleamillefolium, Artemisia Mexicana, Castelatortuosa, Menthapiperita, have a minimal lethal dose of $125 \mathrm{mg} / \mathrm{L}$. Justiciaspcigera and Lippiagraveolens have a $250 \mathrm{mg} / \mathrm{L}$ activity. Artemisia absinthium, Chenopodiumgraveolens, Gymnospermaglutinosum, Limpiacritridora, Populusalba and Thymus vulgaris, have an activity of $500 \mathrm{mg} / \mathrm{L}$ respectively (Tables 1, 2). These results were obtained by means of different repeated tests in the vitro model $[17,18]$.

Then we proceeded to perform a toxicity study by forming various groups using different concentrations of the extracts above. It was found that none of the extracts led to the death of the treated mice. They were observed for 20 days noting their physical appearance and behavior, and it was observed that there was no difference between the control group and the treated group (Table 3) $[19,20]$.

To ensure their safety the mice with the highest dose of extract $(5000 \mathrm{mg} / \mathrm{kg}$ ) were submitted to liver and kidney histopathology and no damage was found to any of the above mentioned organs [21].
Table 3. Toxicity of hexane extracts in CD1 male mice for 20 days.

\begin{tabular}{|c|c|c|c|}
\hline Extract & Dose used & $\begin{array}{l}\text { Animal } \\
\text { number }\end{array}$ & $\begin{array}{l}\text { State of the } \\
\text { animal }\end{array}$ \\
\hline \multirow{5}{*}{$\begin{array}{l}\text { Achilleamillefolium } \\
\text { (Plumajillo) }\end{array}$} & $0.5 \mathrm{mg} / \mathrm{kg}$ & 3 & Good \\
\hline & $5 \mathrm{mg} / \mathrm{kg}$ & 3 & Good \\
\hline & $50 \mathrm{mg} / \mathrm{kg}$ & 5 & Good \\
\hline & 500 mg/kg & 5 & Good \\
\hline & $5000 \mathrm{mg} / \mathrm{kg}$ & 5 & Good \\
\hline \multirow{5}{*}{$\begin{array}{l}\text { Artemisia absinthium } \\
\text { (Ajenjo) }\end{array}$} & $0.5 \mathrm{mg} / \mathrm{kg}$ & 3 & Good \\
\hline & $5 \mathrm{mg} / \mathrm{kg}$ & 3 & Good \\
\hline & $50 \mathrm{mg} / \mathrm{kg}$ & 5 & Good \\
\hline & 500 mg/kg & 5 & Good \\
\hline & $5000 \mathrm{mg} / \mathrm{kg}$ & 5 & Good \\
\hline \multirow{5}{*}{$\begin{array}{l}\text { Artemisia mexicana } \\
\text { (Estafiate) }\end{array}$} & $0.5 \mathrm{mg} / \mathrm{kg}$ & 3 & Good \\
\hline & 5 mg/kg & 3 & Good \\
\hline & $50 \mathrm{mg} / \mathrm{kg}$ & 5 & Good \\
\hline & 500 mg/kg & 5 & Good \\
\hline & $5000 \mathrm{mg} / \mathrm{kg}$ & 5 & Good \\
\hline \multirow{5}{*}{$\begin{array}{l}\text { Castela tortuosa } \\
\text { (Chaparro amargo) }\end{array}$} & $0.5 \mathrm{mg} / \mathrm{kg}$ & 3 & Good \\
\hline & 5 mg/kg & 3 & Good \\
\hline & $50 \mathrm{mg} / \mathrm{kg}$ & 5 & Good \\
\hline & $500 \mathrm{mg} / \mathrm{kg}$ & 5 & Good \\
\hline & $5000 \mathrm{mg} / \mathrm{kg}$ & 5 & Good \\
\hline \multirow{5}{*}{$\begin{array}{l}\text { Justicia spicigera } \\
\text { (muicle) }\end{array}$} & $0.5 \mathrm{mg} / \mathrm{kg}$ & 3 & Good \\
\hline & $5 \mathrm{mg} / \mathrm{kg}$ & 3 & Good \\
\hline & $50 \mathrm{mg} / \mathrm{kg}$ & 5 & Good \\
\hline & 500 mg/kg & 5 & Good \\
\hline & 5000 mg/kg & 5 & Good \\
\hline \multirow{5}{*}{$\begin{array}{l}\text { Lippiagraveolens } \\
\text { (Oregano) }\end{array}$} & $0.5 \mathrm{mg} / \mathrm{kg}$ & 3 & Good \\
\hline & 5 mg/kg & 3 & Good \\
\hline & $50 \mathrm{mg} / \mathrm{kg}$ & 5 & Good \\
\hline & $500 \mathrm{mg} / \mathrm{kg}$ & 5 & Good \\
\hline & $5000 \mathrm{mg} / \mathrm{kg}$ & 5 & Good \\
\hline \multirow{5}{*}{$\begin{array}{l}\text { Menthapiperita } \\
\text { (Mint) }\end{array}$} & $0.5 \mathrm{mg} / \mathrm{kg}$ & 3 & Good \\
\hline & $5 \mathrm{mg} / \mathrm{kg}$ & 3 & Good \\
\hline & $50 \mathrm{mg} / \mathrm{kg}$ & 5 & Good \\
\hline & 500 mg/kg & 5 & Good \\
\hline & $5000 \mathrm{mg} / \mathrm{kg}$ & 5 & Good \\
\hline \multirow{5}{*}{$\begin{array}{l}\text { Populus alba } \\
\text { (Álamo) }\end{array}$} & $0.5 \mathrm{mg} / \mathrm{kg}$ & 3 & Good \\
\hline & 5 mg/kg & 3 & Good \\
\hline & $50 \mathrm{mg} / \mathrm{kg}$ & 5 & Good \\
\hline & 500 mg/kg & 5 & Good \\
\hline & $5000 \mathrm{mg} / \mathrm{kg}$ & 5 & Good \\
\hline \multirow{5}{*}{$\begin{array}{l}\text { Thymusvulgaris } \\
\text { (Tomillo) }\end{array}$} & $0.5 \mathrm{mg} / \mathrm{kg}$ & 3 & Good \\
\hline & $5 \mathrm{mg} / \mathrm{kg}$ & 3 & Good \\
\hline & 50 mg/kg & 5 & Good \\
\hline & 500 mg/kg & 5 & Good \\
\hline & $5000 \mathrm{mg} / \mathrm{kg}$ & 5 & Good \\
\hline
\end{tabular}

Considering these promising results under in vitro conditions and being certain that they are not toxic to mammals we propose that these extracts on the definitive host of these parasites, viz., sheep and cattle be tested [21,22].

\section{Conclusion}

Our results are promising and suggest carrying tests in 
vivo in the definitive host of Fasciola hepatica (cattle or sheep) and do a phytochemical study from plants showed more effective.

\section{Acknowledgements}

This study is supported by project PAPPIT.

\section{REFERENCES}

[1] Basso y Nilda, "Bases de la Parasitología Veterinaria," Hemisferio Sur, México, 1992, p. 157.

[2] F. Ibarra, J. Figueroa and H. Quiroz, "Parasitología Veterinaria Volumen II Helmintos,” UNAM, México D.F., 2011.

[3] Tay and Velasco, "Parasitología Médica,” Editorial Mendez, Séptima Edición, México D.F., 2002

[4] A. Nari and C. Fiel, "Enfermedades Parasitarias de Importancia Económica en Bovinos: Bases Epidemiológicas para su Prevención y Control,” Editorial Hemisferio Sur México D.F., 1988.

[5] F. Froylán, N. Montenegro, Y. Vera, R. Castillo, A. Hernández and P. Ochoa, "Eficacia Comparativa de un Fasciolocida Experimental, Triclabendazol y Closantel en Bovinos Infectados en Forma Natural con Fasciolahepatica," Veterinaria México, Vol. 33, No. 3, 2002, pp. 237-245.

[6] F. Froylán, N. Montenegro, J. Flores, A. Hernández and R. Castillo, "Evaluación de Cuatro Vehículos para Formular un Fasciolocida Experimental,” Veterinaria México, Vol. 1, No. 1, 2000, pp. 1-7.

[7] F. H. M. Borgsteede, "Gastrointestinal Helminthiasis: Anthelmintic Resistance and How to Prevent and Control,” Symposium Parasitology International, Vol. 47, 1998, pp. 23-48.

[8] J. Rzedowski, “Vegetación de México,” LIMUSA, México, 1978, p. 472.

[9] J. Díaz, “Índice y Sinonimias de las Plantas Medicinales de México. Instituto Mexicano para el Estudio de las Plantas Medicinales,” Instituto de Investigaciones Biomédicas, UNAM, México D.F., 1976.

[10] M. Columba and E. Castillo, "Plantas Medicinales Utilizadas en el Estado de Morelos," Universidad Autónoma del estado de Morelos Conabio, Mexico, 2007, p. 405.

[11] G. Dominguez, M. Ángel and B. Aguilar, "El Mercado de Plantas Medicinales en México Situación Actual y Perspectivas de Desarrollo,” 2004. http://www.herbotecnia.com.ar/c-public-003.html

[12] J. Vercruysse, P. Holdsworth, T. Letonia, D. Barth, G. Conder and K. Hamamoto, "International Harmonisation of Anthelmintic Efficacy Guidelines,” Veterinary Parasitology, Vol. 96, No. 6, 2001, pp. 171-193.

\section{doi:10.1016/S0304-4017(00)00443-X}

[13] N. Rivera, F. Ibarra, A. Zepeda, T. Fortoul, A. Hernandez and R. Castillo, "Tegumental Surface Changes in Adult Fasciola hepatica Following Treatment in Vitro and in Vivo with an Experimental Fasciolicide,” Parasitology Research, Vol. 93, No. 4, 2004, pp, 283-286. doi:10.1007/s00436-004-1127-3

[14] F. Ibarra and D. C. Jenkins, "An in Vitro Screen for New Fasciolicidal Agents,” Parasitology Research, Vol. 70, No. 5, 1984, pp. 655-661. doi:10.1007/BF00926594 http://www.springerlink.com/content/h2321x15g416t701/ fulltext.pdf

[15] S. Ibarra-Moreno, F. Ibarra and J. G. Avila, "In Vitro Evaluation of Fasciolicide Activity with Hexane, Metanol and Ethyl Acetate with Extracts Processed and Obtained from Some Mexican Plants Used in Traditional Medicine Based on Ethno Botanical Studies," American Journal of Plant Sciences (AJPS), Vol. 3, No. 4, 2012, pp. 506-511.

[16] T. Hernández, M. Canales, J. G. Avila, A. Duran, J. Caballero, A. Romo de Vivar and R. Lira, "Ethnobotany and Antibacterialactivity of Someplantsused in Traditional Medicine of Zapotitlán de las Salinas, Puebla (México),” Journal of Ethnopharmacology, Vol. 88, No. 2, 2003, pp. 181-188.

[17] M.Pascual, K. Slowing, E. Carretero, D. Sánchez Mata and A. Villar, "Lippia: Traditional Uses, Chemistry and Pharmacology,” Journal of Ethnopharmacology, Vol. 76, No. 3, 2011, pp. 201-214. doi:10.1016/S0378-8741(01)00234-3

[18] D. Bahuaud, C. Martínez-Ortiz de Montellano, S. Chauveau, F. Prevot, F. Torres-Acosta, I. Fouraste and H. Hoste, "Effects of Four Tanniferous Plant Extracts on the in Vitro Exsheathment of Third-Stage Larvae of Parasitic Nematodes,” Parasitology, Vol. 132, No. 6, 2005, pp. 545-554.

[19] M. Sachana and A. J. Hargreaves, “Toxicological Testing: in Vitro and in Vivo Models. En: Veterinary Toxicology: Basic and Clinical Principles," Academic Press, New York, 2007.

http://www.ropana.cl/Toxivet/Relacion\%20Dosis-Respue sta.htm

[20] C. Klaaseen and J. Watkins III, "Fundamentos de Toxicología,” Mc Graw Hill Interamericana, México, 2005, p. 536.

[21] A. Lagarto, J. Tillán, R. Vega and Y. Cabera, “Toxicidad Aguda oral de Extractos Hidroalcohólicos de Plantas Medicinales," Revista Cubana de Plantas Medicinales, Vol. 1, No. 4, 1999, pp. 8-26.

[22] M. Rivera, L. Macías, M. Tinoco, I. García and I. Ruíz, "Toxicidad Aguda en rata y Ratón de la Casiopeína (gli)," 2do. Congreso Nacional de Química Médica (CNQM) 2000. 